\title{
Paternalisme på fremmarsj?
}

Det er et forgrenet regelverk som åpner for bruk av tvang i dagens helselovgivning. Reglene finnes blant annet i psykisk helsevernloven, smittevernloven, pasient- og brukerrettighetsloven, helse- og omsorgstjenesteloven og helsepersonelloven. I Tidsskriftet er det i løpet av kort tid publisert tre bidrag der det er problematisert at det ikke kan anvendes tvang i flere situasjoner enn dagens regelverk åpner for.

Sist ut er Dahlberg \& Dahl, som i dette nummer av Tidsskriftet har en spennende artikkel om muligheten til å tvangsernære en sultestreikende asylsøker (1). Jeg kommer tilbake til deres bidrag. En sultestreikende person er beskyttet mot paternalistisk intervensjon etter pasient- og brukerrettighetsloven $\S 4-9$, også når dette skjer i vedkommendes interesse og hjelpen fremstår som «påtrengende nødvendig» (2). Bahus \& Førde har reist tilsvarende betenkeligheter overfor den samme bestemmelsen, som gir personer rett til å nekte mottak av blod og blodprodukter (3). Sammen med døende som nekter livsforlengende behandling er dette de tre særlig beskyttede pasientgruppene med vern mot paternalistisk inngripen.

Det tredje bidraget er en leder av Frøland om smittevernlovens tvangsbestemmelser, som han ønsker utvidet (4). Bestemmelsene er blitt svært lite benyttet gjennom de snart 30 årene som loven har vært i kraft, og Frøland argumenterer godt for enkelte mindre lovendringer for bedret oppfølging og behandling av pasienter med smitteførende tuberkulose.

Bare i begrenset utstrekning presenteres bidrag som argumenterer for en større vektlegging av voksne personers autonomi, et sentralt medisinsketisk prinsipp (5). Felles for bidragene er at de omhandler tvang overfor kompetente personer. Dette er ikke minst situasjonen for dem som gjennomfører sultestreik eller nekter blodtransfusjon, noe som har vært velkjente «dilemmaer» for helsetjenesten i mange år. Sultestreiken enkelte samer iverksatte for å protestere mot Alta-utbyggingen, ble «ufarliggjort» av helsepersonells inngripen og innleggelser i sykehus da enkelte av de streikende begynte å bli dårlige (6).

Blodtransfusjon nektes stort sett på religiøst grunnlag, selv om loven ikke stiller krav om nektingsgrunnlaget så lenge det er basert på en «alvorlig overbevisning». Spørsmålene ble drøftet bredt i høringsutkastet til loven i 1997. Deretter ble pasientrettighetsloven $\S 4-9$ og helsepersonelloven $\S 7$ vedtatt med den ordlyden de i dag har. Under lovbehandlingen i Stortinget stemte representantene fra Fremskrittspartiet for følgende forslag: «Pasienten har ikke pga. alvorlig overbevisning rett til å nekte å motta blod eller blodprodukter eller til å nekte å avbryte en pågående sultestreik.»

Uttrykket «alvorlig overbevisning» ble hentet fra militærnekterloven, der Høyesterett i flere dommer fastla nærmere krav til en «alvorlig» overbevisning, herunder til overbevisningens fasthet og styrke (7).

Mens Dahlberg \& Dahl aksepterer gjeldende lovgivning og problematiserer de etiske og rettslige dilemmaene helsepersonell kan komme opp i, synes Bahus \& Førde å ville ugyldiggjøre en klar og gjennomtenkt lovregulering, og uten kritisk rettskildebruk.

De har heller ikke gjort seg kjent med Den europeiske menneskerettsdomstolens avgjørelse i saken Jehovah's witnesses of Moscow and others v. Russia fra mai 2010. Her anerkjenner Strasbourg-domstolen nektingsretten til en kompetent pasient, selv om det kan resultere $\mathrm{i}$ «a fatal outcome». Å underkjenne en slik nektingsrett krenker retten til fysisk integritet og strider mot Den europeiske menneskerettskonvensjon artikkel 8. Det samme prinsippet er understreket ved en ny bestemmelse i Grunnloven $§ 102$, gyldig fra mai 2014: «Statens myndigheter skal sikre et vern om den personlige integritet.»

I smitteverntilfellene er det ikke bare pasientens eget beste som vektlegges, men det at smitterisikoen i samfunnet øker når mange personer med smitteførende tuberkulose «forsvinner» ut av behandlingsopplegg. En sikring av de øvrige borgeres helsetilstand spiller da inn på en helt annen måte enn når enkeltindivider tvangsbehandles mot deres alvorlige overbevisning.

Dahlberg \& Dahl mener å påvise inkonsistens i regelverket ved at det fremstår som «noe tilfeldig» med de to unntakene for sultestreik og reservasjon mot blodprodukter. De skriver videre: «Dersom eksempelvis vår pasient $\mathrm{i}$ stedet hadde uttrykt sin politiske demonstrasjon ved å tenne på seg selv, ville forholdet ikke vært unntatt fra hjelpeplikten i helsepersonelloven $\S 7 . »$ De finner det lite forståelig «at valget av dødsmåte skal være utslagsgivende for om hjelpeplikten eller pasientautonomien skal ha forrang».

Her går de i en «konsekvensfelle» - ved at den som i affekt tenner på seg selv, kan være psykisk ustabil som andre som begår suicid, og da er hjelpeplikten absolutt. Sultestreiken til deres pasient var opprettholdt i fem uker, noe som understreket vedkommendes alvorlige overbevisning.

Ved lesingen av deres spennende og utfordrende fremstilling savnet jeg svar på et viktig spørsmål: Hvordan gikk det med pasienten? Jeg kontaktet forfatterne, som sa han hadde samtykket $\mathrm{i}$ at følgende del av sykehistorien ble publisert. De fant etter sakkyndig vurdering at pasienten var beslutningskompetent og hadde en alvorlig overbevisning. Loven ble etterlevd ved å informere om at de ikke hadde rett til å gripe inn. Sultestreiken ble avsluttet etter at det var tydeliggjort for ham at loven ikke åpnet for tvangsinngrep i den konkrete situasjonen.

Det fremstår som en bra løsning for så vel pasient som helsepersonell at pasienten selv kunne ta en slik beslutning. Ikke minst viste vel denne løsningen at lovverket på dette feltet er mer gjennomtenkt enn forfatterne selv legger til grunn i sin fremstilling?

\section{Aslak Syse}

aslak.syse@jus.uio.no

Aslak Syse (f. 1946) er professor i rettsvitenskap ved Universitetet i Oslo. Han har tidligere arbeidet i ulike legestillinger i 20 år.

Forfatter har fylt ut ICMJE-skjemaet og oppgir ingen interessekonflikter.

Litteratur

1. Dahlberg J, Dahl V. Sultestreikende asylsøker - hvor langt går pasientens rett til å nekte behandling? Tidsskr Nor Legeforen 2015; 135: 45-7.

2. LOV-1999-07-02-63. Lov om pasient- og brukerrettigheter (pasient- og brukerrettighetsloven). https://lovdata.no/dokument/NL/lov/1999-07-02-63 (7.7.2014)

3. Bahus M, Førde R. Når pasienten nekter blodoverføring. Tidsskr Nor Legeforen 2014; 134: 850-1.

4. Frøland SS. Når tvang er nødvendig. Tidsskr Nor Legeforen 2014; 134: 1342

5. Childress JF, Beauchamp TL. Principles of biomedical ethics. Oxford: Oxford University Press, 2009

6. Hjorthol LM. Alta - kraftkampen som utfordret statens makt. Oslo: Gyldendal, 2006.

. Norsk Retstidende 1996; 87: 572. 